連絡先

(米国)

Kazuo Misumi, M.D., F.A.C.C., F.A.C.P., F.C.C.P., 1441 Kapiolani Blvd., Suite ${ }^{\#} 805$,

Honolulu, Hawaii 96814, U.S.A.

Tel 808-941-3998/Fax 808-941-3933
(日本)

₹270-2251

千葉県松戸市金ヶ作107-1

千葉西総合病院心臓センター

Tel 047(384)8111/Fax 047(389)5162

\title{
用语周説
}

\section{Head-up tilt table testing (HUT)}

神経失調性失神を診断するさいの検査法と して gold standard になっている. HUT に より誘発される失神の機序は, BezoldJarisch 反射によるものと考えられている. すなわち静脈還流量が減少し，代償性に心拍 数が増加し，心室収縮力が増大する。室の 収縮が過剩になりいわゆる “空打現象”が起 きて，心室内のメカノレセプターが刺激され ると求心性迷走神経の発火が起こり中枢に招 いて遠心性迷走神経が立進して心拍数を減少 させ，また交感神経活動が低下し，末梢血管 の拡張をきたし血圧が低下すると考えられて いる.

HUT の方法としては，まず薬剤負荷を行 わずに行う，角度は $60^{\circ}$ から $80^{\circ}$ ，時間は 30 45分が適当之考えられており，誘発されな い場合はプロタノールの負荷またはニトログ リセリン負荷を行いHUTを10分間行うと 誘発率が増す。血圧および心電図モニターが 必要である，血圧は連続してモニター可能な
システム（トノメトリーなど）が望ましい。 まれにではあるが心停止をきたす例もあり， 救急救命セット（除細動器, マスクバッグ, アトロピン，ノルアドレナリンなど）の準備 が必要である，血圧が低下すると気分不良， 下肢脱力感, 眼前暗黑感などの前失神状態が 出現し継続すると失神する，心拍と血圧の反 応から(1)心抑制型（心拍数が著明に減少）, (2)血管抑制型（血圧が著明に低下），(3)混合 型の 3 型に分類される．失神発作時に外傷 を負う例や，危険な職業（運転手，土木・建 築作業員など）に従事している例，症状が強 く社会生活が普通に送れない場合などは薬剤 による治療を行う，神経失調性失神にはジソ ピラミドなどの Ia の抗不整脈， $\beta$ 遮断薬な ぞが有効なことが多いが， $\beta$ 遮断薬では逆に 誘発されやすい例もあり，投与後に HUT で 誘発されないことを確認する必要がある。

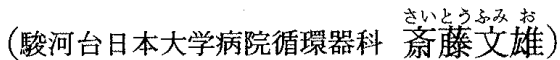

